\title{
Gender as a factor in differentiating strategies of coping with stress used by physical education students
}

\section{BACKGROUND}

Students are exposed to numerous stressors associated with their integration into their university education, their relationships with friends, and anxiety about the future. Given that stress may be related to university students' academic performance, understanding the coping strategies used by students may be important in facilitating a positive transition to a university setting. The aim of this study was to determine the gender-based variation of strategies for coping with stress used by students, as well as to determine the correlation between these strategies and the students' academic achievements.

\section{PARTICIPANTS AND PROCEDURE}

The study design was cross sectional and included 376 first-year undergraduate students (227 men and 149 women) enrolled in the physical education and sport programme at the University of Physical Education in Warsaw. The Polish adaptation of Carver, Scheier and Weintraub's Multidimensional Inventory for Measuring Stress Coping - COPE and the mean grade from all first-year university courses (the indicator of academic achievements) were used.

\section{RESULTS}

Men definitely preferred task-oriented strategies, while women preferred to look for support (instrumental and emotional) and placed higher importance on the focusing on and venting of emotions. Academic achievement correlated positively with task-oriented strategies and negatively with avoidance-oriented strategies. These relationships were partly confirmed by regression analyses.

\section{CONCLUSIONS}

The results of the study provide support for sex differences in the most frequently applied coping strategies. The results also suggest that avoidance-oriented strategies do not facilitate academic achievement, while active coping strategies correlate with greater success in studies.

\section{KEY WORDS}

students; coping styles; academic achievements

ORganization - 1: Department of Socio-cultural Foundations of Tourism, The Jozef Piłsudski University of Physical Education, Warsaw, Poland · 2: Department of Psychology, The Faculty of Physical Education, The Jozef Pilsudski University of Physical Education, Warsaw, Poland

AUthors' Contributions - A: Study design - B: Data collection - C: Statistical analysis - D: Data interpretation .

E: Manuscript preparation · F: Literature search · G: Funds collection

CORRESPONDING AUTHOR - Adriana Zagórska-Pachucka, Ph.D., Department of Psychology, The Faculty of Physical Education, The Jozef Pilsudski University of Physical Education, 34 Marymoncka Str., 00-968 Warsaw, Poland, e-mail: adazagorska@wp.pl

TO CITE THIS ARTICLE - Guszkowska, M., Zagórska-Pachucka, A., Kuk, A., \& Skwarek, K. (2016). Gender as a factor in differentiating strategies of coping with stress used by physical education students. Health Psychology Report, 4(3), 237-245. doi: 10.5114/hpr.2016.57681

RECEIVED 10.11.2015 · REVIEWED 15.12.2015 · ACCEPTED 11.01.2016 · PUBLISHED 15.02.2016 


\section{BACKGROUND}

Students are exposed to numerous stressors connected to their integration into their university education, their relationships with friends, and anxiety about the future (Brougham, Zail, Mendoza, \& Miller, 2009; Pierceall \& Keim, 2007). Guthrie et al. (1995) categorised these stressors into three groups: academic pressure, social pressure, and financial pressure. The main sources of stress for medical students in Poland

Monika Guszkowska, Adriana ZagórskaPachucka, Anna Kuk, Katarzyna Skwarek were examinations and tests of knowledge, unclear expectations from teachers, and the teachers' dismissive attitudes towards students; the main causes of stress in non-academic areas were family and financial problems (Rosołowska, 2003; Wilczek-Rużyczka \& Jabłeka, 2013). The first year of studies is especially difficult for students due to adaptational challenges. The stress caused by these challenges may be intensified by problems related to the transition from adolescence to adulthood (Dyson \& Renk, 2006). Severe stress can reduce students' self-esteem, lower their learning capabilities, and consequently diminish their potential academic achievements (Chew-Graham, Rogers, \& Yassin, 2003; Fish \& Nies, 1996; Niemi \& Vainiomaki, 1999; Silver \& Glicken, 1990). Given that stress may be related to university students' academic performance, understanding the coping strategies used by students may be important in facilitating a positive transition to a university setting.

According to the already established definition, coping with stress involves constantly changing cognitive and behavioural efforts to manage specific external and/or internal demands that are appraised as taxing (Lazarus \& Folkman, 1984). Coping fulfils protective functions, i.e. it can lower the level of experiencing stress and reduce its negative consequences also for school and university youths. Studies among lower-secondary school students indicated that effective and appropriate strategies for coping with stress might moderate the influence of newly encountered difficult situations, especially those that affect physical and mental health (Park \& Adler, 2003).

There are three most commonly distinguished styles of coping with stress (Endler \& Parker, 1990). The target-oriented style involves treating difficult situations as problems to be solved. Persons who prefer task-oriented strategies in a stressful situation undertake efforts aimed at solving a problem through cognitive transformations or attempting to change the situation. The main focus lies on completing a task or planning how to solve a problem. The emotion-oriented style manifests itself as a person's tendency to be focused on themselves, on their own emotional experiences such as anger, guilt, and tension, and their inclination to wishful thinking and fantasising. The avoidance-oriented style involves avoiding thinking about and experiencing a stressful situation, and may manifest itself as engaging in such displacement activities as watching TV, sleeping, thinking about pleasant things, and seeking friendly social contacts (Endler \& Parker, 1990).

Carver, Scheier, and Weintraub (1989) emphasised the need to distinguish between a coping style and a coping strategy. Style describes dispositions for handling stress, while strategy describes methods used in a given stressful situation.

According to the studies, the method for dealing with stress applied by students in a given situation to a large extent depends on their coping styles (Gan \& Anshel, 2006; Kausar, 2010); but it also varies according to gender, skills, sources of stress, and the character of a situation (Gan \& Anshel, 2006). Situational variables have a greater influence on the adoption of avoidance-oriented strategies, while personality traits and the type of situation are more significant for undertaking task-oriented strategies (Anshel \& Delany, 2001). The choice of a coping method may be related to how a given event is interpreted. Men and women differ in this regard (Robinson \& Johnson, 1997).

Students' preferences concerning the methods for managing stress vary not only according to their field of study (Wilczek-Rużyczka \& Jabłeka, 2013) but also according to their specialisation (Guszkowska, 2003). Polish students of medicine, nursing, and pedagogy most often undertook task-oriented actions (Guszkowska, 2003; Wilczek-Rużyczka \& Jabłeka, 2013).

Nepalese students most often used the following coping strategies: active coping, positive reappraisal, planning, engaging in displacement activities, and seeking social support (Sreeramareddy et al., 2007). In Ajman (the United Arab Emirates) the main strategies observed were displacement activities, active coping, positive reappraisal, planning, and acceptance (Gomathi, Ahmed, \& Sreedhran, 2013). Nigerian students most often chose to turn to religion; apart from that, they used such strategies as planning, acceptance, and seeking instrumental support. Men chose denial more often than women (Yussuf, Issa, Ajiboye, \& Buhari, 2013). Therefore, the study results suggest that preferences concerning coping strategies may be culturally diverse.

This may be the reason for the inconsistency of results concerning the differences of coping strategies according to sex (Thornton, Pickus, \& Aldrich, 2005). College women usually reported greater use of emotion-focused coping strategies (Brougham et al., 2009; Eaton \& Bradley, 2008; Stanton, Kirk, Cameron, \& Danoff-Burg, 2000) and social support (Dwyer $\&$ Cummings, 2001). Research has not found a clear pattern of sex differences in the use of task-oriented strategies to cope with stress (Dyson \& Renk, 2006; Pritchard \& Wilson, 2006).

When researching the coping strategies used by Australian athletes in sports rivalry, Goyen and An- 
shel (1998) found that men preferred task-oriented strategies and women preferred emotion-oriented strategies. Similar sex differences were found in the use of coping strategies among Israeli athletes (Anshel, Jamieson, \& Raviv, 2001) and United States endurance athletes (Hammermeister \& Burton, 2004). Lane, Jones and Stevens (2002) found no gender differences in coping with failure among male and female tennis players.

Research among students in Turkey (Kaya, Genç, Kaya, \& Pehlivan, 2007) and the UK (Moffat, McConnachie, Ross, \& Morrison, 2004) yielded similar results. On the other hand, research by Kao and Craigie (2013) conducted among university students in Taiwan, and research by Dyson and Renk (2006) on American students, did not reveal any differences between men and women in stress coping strategies. Thornton, Pickus, and Aldrich (2005) established that strategies are more dependent on students' gender than their biological sex. Male medical students in Aruba more often turn to humour as a coping strategy than female students (Shankar et al., 2014).

According to research by Romanowska-Tołłoczko (2011), students at the universities of physical education (PE) in Poland were the least exposed to stress related to studying in comparison to students attending other Polish universities. The main causes of stress for the PE students were learning, meeting educational requirements, and tiredness. Stress was also caused by financial difficulties, family problems, and emotional problems (Romanowska-Tołłoczko, 2011). The PE students used methods of coping with a stressful situation that had an extreme effect on their health. Most often, they relieved mental tension through physical activity; however, they also were the most likely to admit that drinking alcohol is a good method for reducing stress. There are, however, no data on the differences in strategies for coping with stress used by male and female PE students and their relationships with academic achievement.

Two research questions were formulated: 1 . Are there differences in coping strategies between male and female PE students? 2. What are the relationships between the coping strategies used by PE students and their academic achievements?

Based on the results of earlier studies, two hypotheses were formulated: 1 . Women are more likely to use emotion-oriented strategies than men. 2. There is a positive correlation between task-oriented strategies and average grade obtained in the first year.

\section{PARTICIPANTS AND PROCEDURE}

The study design was cross sectional. The study included 376 first-year undergraduate students (227 men and 149 women) enrolled in the physical education and sport programme at the University of
Physical Education in Warsaw. The participants were between 18 and 26 years old $(M=20.08, S D=1.06)$.

The Polish adaptation of Carver, Scheier and Weintraub's Multidimensional Inventory for Measuring Stress Coping - COPE prepared by Juczyński and Ogińska-Bulik (2009) was used. This questionnaire is a tool for measuring dispositional coping - that is, for evaluating typical ways of reacting to stress. It has 60 statements comprising 15 coping strategies (active coping, planning, avoiding competitive activities, positive reappraisal and development, restraining from action, denial, behavioural disengagement, humour, distraction, drinking alcohol, acceptance, seeking emotional support, seeking instrumental support, turning to religion, and the focus on and venting of emotions), which form three second-order factors: active coping, avoidance-oriented coping, and seeking support and focus on emotions. Respondents have a four-point answer format at their disposal: 1 - I never do this; 2 - I rarely do this; 3 - I often do this; and 4 - I almost always do this. The result is calculated by dividing the sum of the points within each scale (factor) by the number of statements. Thus, the result always ranges between 1 and 4 . The indicators of internal consistency (Cronbach's $\alpha$ ) are as follows: turning to religion .94, drinking alcohol .91, humour .84, seeking emotional support .83, acceptance .79 , seeking instrumental support .77, behavioural disengagement .74, the focus on and venting of emotions .71, planning .71 , positive reappraisal and development .68 , denial .60 , avoiding competitive activities .54 , restraining from action .53 , active coping .49, distraction .48. In the last four scales coefficients are lower than .60 , so their scores must be interpreted with caution. The indicators of stability determined during studies conducted at six-week intervals ranged between .45 and .82. Diagnostic validity was confirmed by correlations, consistent with expectations, of the results of COPE with the results of other coping strategy scales and personality inventories.

The study used as the indicator of academic achievements the mean grade from all first-year university courses obtained by those students who were entitled to proceed to the second year of studies. Since in the first year, all courses were obligatory, the average was calculated in the same way for all students. The grades of 17 courses were taken into account, including 9 theoretical courses (anatomy, biochemistry, biology, pedagogics, psychology, ethics, theory of physical education, history of physical culture, organisation and law in education) and 8 practical courses (callisthenics and dance, methodology of gymnastics, methodology of swimming, methodology of track and field, methodology of basketball, methodology of volleyball, plays and games, summer camp).

The average grade varied from 2.77 to 4.79 $(M=3.50, S D=0.35)$. It was obtained for 282 students
Gender as a factor in differentiating strategies 
(including 178 men and 104 women). The difference in the number of subjects resulted from the fact that 94 students (49 men and 45 women) did not complete the first year of study.

The study could not be anonymous, because it was necessary to combine the COPE scores with academic grades. All subjects gave consent to participate in the research. They could also receive feedback on the results obtained. The research project was accepted by the Senate Committee on Research Ethics of Jozef Pił-

Monika

Guszkowska,

Adriana

Zagórska-

Pachucka,

Anna Kuk,

Katarzyna Skwarek

A one-way ANOVA was conducted in order to determine gender differences. To determine the relationships between the results of the COPE inventory and the average grade the Pearson product-moment separately for men and women, and for both sexes combined. Academic achievement predictors were determined using stepwise regression analysis with average grade as the dependent variable, separately for men and women, and for students of both sexes. All coping strategies were introduced in regression equations as predictors. All statistical analyses were performed using the statistical IBM package SPSS19 (SPSS Inc., Chicago, IL).

\section{RESULTS} correlation coefficients (Pearson's $r$ ) were calculated,
Table 1 presents the descriptive statistics for the results of men and women within each scale of the COPE inventory and within the three factors, including rank, as well as the results of the one-way ANOVA. Rank 1 was assigned to the strategy with

Table 1

Coping strategies by gender - descriptive statistics and ANOVA

\begin{tabular}{|c|c|c|c|c|c|c|c|c|c|}
\hline \multirow[t]{2}{*}{ Coping strategies } & \multicolumn{3}{|c|}{ Male $(n=227)$} & \multicolumn{3}{|c|}{ Female $(n=149)$} & \multirow[t]{2}{*}{$F(1,375)$} & \multirow[t]{2}{*}{$\eta^{2}$} & \multirow[t]{2}{*}{$p$} \\
\hline & $M$ & $S D$ & rank & $M$ & $S D$ & rank & & & \\
\hline Active coping & 2.96 & 0.40 & 2 & 2.82 & 0.48 & 3 & 11.01 & .03 & .001 \\
\hline Planning & 2.96 & 0.65 & 2 & 2.80 & 0.58 & 4 & 9.08 & .02 & .003 \\
\hline $\begin{array}{l}\text { Positive reappraisal } \\
\text { and development }\end{array}$ & 2.94 & 0.62 & 3 & 2.73 & 0.57 & 6 & 6.56 & .02 & .011 \\
\hline $\begin{array}{l}\text { Avoiding competitive } \\
\text { activities }\end{array}$ & 2.68 & 0.59 & 4 & 2.48 & 0.62 & 9 & 13.71 & .03 & $<.001$ \\
\hline $\begin{array}{l}\text { Restraining from } \\
\text { action }\end{array}$ & 2.56 & 0.53 & 6 & 2.54 & 0.55 & 8 & 0.15 & .01 & .699 \\
\hline $\begin{array}{l}\text { Seeking instrumental } \\
\text { support }\end{array}$ & 2.61 & 0.71 & 5 & 2.87 & 0.74 & 1 & 7.02 & .02 & .008 \\
\hline $\begin{array}{l}\text { Seeking emotional } \\
\text { support }\end{array}$ & 2.33 & 0.76 & 9 & 2.83 & 0.79 & 2 & 31.45 & .08 & $<.001$ \\
\hline $\begin{array}{l}\text { Focus on and venting } \\
\text { of emotions }\end{array}$ & 2.36 & 0.68 & 8 & 2.77 & 0.83 & 5 & 25.83 & .07 & $<.001$ \\
\hline Turning to religion & 1.97 & 0.95 & 12 & 2.18 & 0.99 & 11 & 4.14 & .01 & .043 \\
\hline Acceptance & 2.51 & 0.76 & 7 & 2.60 & 0.62 & 7 & 1.44 & .01 & .231 \\
\hline Distraction & 2.09 & 0.55 & 11 & 2.34 & 0.57 & 10 & 12.83 & .03 & $<.001$ \\
\hline Humour & 2.10 & 0.78 & 10 & 1.96 & 0.81 & 12 & 1.02 & .01 & .314 \\
\hline Denial & 1.75 & 0.63 & 13 & 1.79 & 0.55 & 14 & 0.13 & .01 & .723 \\
\hline $\begin{array}{l}\text { Restraining from } \\
\text { action }\end{array}$ & 1.68 & 0.56 & 14 & 1.88 & 0.69 & 13 & 7.93 & .02 & .005 \\
\hline Drinking alcohol & 1.61 & 0.76 & 15 & 1.71 & 0.88 & 15 & 1.69 & .01 & .194 \\
\hline Active coping & 2.82 & 0.36 & I & 2.68 & 0.35 & I & 16.52 & .04 & $<.001$ \\
\hline $\begin{array}{l}\text { Seeking support and } \\
\text { focus on emotions }\end{array}$ & 2.31 & 0.54 & II & 2.66 & 0.61 & II & 27.61 & .07 & $<.001$ \\
\hline $\begin{array}{l}\text { Avoidance-oriented } \\
\text { coping }\end{array}$ & 1.96 & 0.37 & III & 2.05 & 0.39 & III & 4.87 & .01 & .028 \\
\hline
\end{tabular}


the highest score, and therefore the most frequently used by students to cope with stress.

Comparing the ranks of strategies between the groups of female students and male students reveals certain differences. Men clearly prefer task-oriented strategies (strategies ranked between first and seventh). The first strategy belonging to the "seeking support and focusing on emotions" factor (seeking instrumental support) ranked fifth. Women prefer seeking support (instrumental and emotional) and place higher importance on the focusing on and venting of emotions when compared with men. Task-oriented strategies placed third and fourth, and then from sixth to ninth. Both men and women gave similar ranks to avoidance-oriented behaviours: acceptance was ascribed the highest rank (it placed seventh), and drinking alcohol placed last. The hierarchy of the three factors is the same among male students and female students.

These ranks provide us with information about the frequency of using the various strategies. A comparison of the women's scores with the men's scores was conducted, which allowed differences in absolute values to be determined. The results of the comparison indicate that the male students use almost all task-oriented strategies (apart from restraining from action) significantly more often than female students; they also obtained higher results in the active coping factor. In turn, female students apply all four strategies related to seeking support and the focusing on and venting of emotions more often than male students, thus obtaining a higher score in the relevant factor. Women, more often than men, manage stress by behavioural disengagement and distraction; therefore, the score in the avoidance behaviours factor was much higher among women than among men. The two groups do not differ with regard to the other avoidance-oriented strategies. Gender-related differences were observed in 10 out of 15 scales and among all three factors.

Male students achieved a lower average grade $(M=3.43, S D=0.34)$ than women $(M=3.62, S D=0.33)$, and this difference was statistically significant $\left(F(1,281)=22.01, p<.001, \eta^{2}=.07\right)$.

The Pearson product-moment correlation coefficient (Pearson's $r$ ) between the results of the COPE inventory and the average grade are presented in Table 2 . Throughout the entire group, academic results positively correlated with task-oriented strategies - active coping and planning - and correlated negatively with avoidance-oriented strategies - denial, drinking alcohol and consuming other psychoactive substances, and distraction.

Significant positive correlations in the group of male students were observed with respect to active coping and planning; negative correlations were observed with drinking alcohol, denial, behavioural disengagement, and distraction. In the group of female students, the average grade obtained for firstyear university courses correlated positively with active coping and planning, but also with avoiding competitive activities; negative correlations were

Table 2

Correlations between average grade and coping strategies for male, female and all students

\begin{tabular}{lccc}
\hline Coping strategies & Men $(n=178)$ & Women $(n=104)$ & All students $(n=282)$ \\
\hline Active coping & $.25^{* *}$ & $.29^{* *}$ & $.22^{* *}$ \\
Planning & $.25^{* *}$ & $.27^{*}$ & $.20^{* *}$ \\
Positive reappraisal and development & .07 & .06 & .01 \\
Avoiding competitive activities & .12 & $.22^{*}$ & .10 \\
Restraining from action & .05 & -.11 & -.02 \\
Seeking instrumental support & -.02 & .11 & .08 \\
Seeking emotional support & -.03 & -.10 & .04 \\
Focus on and venting of emotions & .05 & .01 & .10 \\
Turning to religion & .05 & .09 & .10 \\
Acceptance & -.13 & .02 & -.06 \\
Distraction & $-.16^{*}$ & $-.24^{*}$ & $-.13^{*}$ \\
Humour & -.13 & .01 & -.09 \\
Denial & $-.21^{* *}$ & -.16 & $-.17^{* *}$ \\
Restraining from action & $-.17^{*}$ & -.13 & -.11 \\
Drinking alcohol & $-.25^{* *}$ & -.01 & $-.17^{* *}$ \\
\hline
\end{tabular}

Note. ${ }^{*} p<.05,{ }^{* *} p<.01$ 
observed with distraction. Interestingly, in women, drinking alcohol and consuming other psychoactive substances had no relationship with their academic results. Regardless of a person's gender, task-oriented strategies (active coping and planning) were positively correlated with academic achievement, while the relationships with avoidance-oriented strategies (denial, distraction, behavioural disengagement, and consuming psychoactive substances) were negative.

Table 3 presents the results of the last step of Monika Guszkowska, Adriana ZagórskaPachucka, Anna Kuk, Katarzyna Skwarek the stepwise regression analysis conducted both for the entire group of students and separately for men and women. Throughout the entire group, four predictors explaining less than $9 \%$ of average grades were distinguished: two positive predictors (active coping and focusing on and venting emotions) and two negative predictors (denial and use of alcohol

and psychoactive substances). As far as the group of men is concerned, planning (positive predictor), and both drinking alcohol and distraction (negative predictors), allow for the prediction of $11 \%$ of average grade variability. In the group of women, the model explains $12 \%$ of the variability of the average grade that can be predicted on the basis of active coping (positive predictor) and distraction (negative predictor). The result of the regression analysis confirms the positive relationships between academic achievement and task-oriented strategies and the negative relationships with avoidance-oriented strategies.

\section{DISCUSSION}

Studies among Polish physical education students showed the existence of gender-dependent differences in the most frequently applied coping strategies. Women obtained higher results in all strategies comprising the seeking support factor and the fo-

cusing on emotions factor. The first hypothesis was thus confirmed. The same differences were found in the standardisation research of the COPE inventory (Juczyński \& Ogińska-Bulik, 2009) and in studies on coping styles in the general population and among students of other universities in Warsaw - that is, women obtained higher results than men in the CISS emotion-oriented scale (Strelau, Jaworowska, Wrześniewski, \& Szczepaniak, 2005).

Men studying at the University of Physical Education in Warsaw obtained higher results than women in almost all active coping strategies. In the standardisation research, differences occurred only in the active coping scale (Juczyński \& Ogińska-Bulik, 2009); men and women (general population and students) did not differ in terms of task-oriented coping style (Strelau et al., 2005).

Female students at the University of Physical Education had a greater inclination than male students towards the use of two avoidance-oriented strategies, distraction and behavioural disengagement. These differences were not observed in the standardisation studies (Juczyńki \& Ogińska-Bulik, 2009). Men’s stronger inclination to use humour and drink alcohol, as previously described (Juczyński \& Ogińska-Bulik, 2009), was not found.

In previous studies, college students' use of problem-focused strategies was associated with better health and reduced negative affect (Dunkley, Blankstein, Halsall, Williams, \& Winkworth, 2000; Sasaki \& Yamasaki, 2007), while college students' use of emotion-oriented and avoidance strategies was associated with poorer health and increased negative affect (Pritchard, Wilson, \& Yamnitz, 2007). Brougham et al. (2009, pp. 86-87) concluded "Although a definitive conclusion has not been reached, in general, college students' coping strategies that use action, acceptance, and positive reframing in response to stress were found to be adaptive, while coping strategies

Table 3

Predictors of average grade (the results of the last step of the stepwise regression analyses)

\begin{tabular}{|c|c|c|c|c|c|}
\hline Group & Variable & $\beta$ & $t$ & $p$ & $R^{2}$ \\
\hline \multirow{4}{*}{ Entire group } & Active coping & .19 & 3.18 & .002 & \multirow{4}{*}{$.09^{* * *}$} \\
\hline & Focus on and venting of emotions & .14 & 2.45 & .015 & \\
\hline & Drinking alcohol & -.14 & 2.36 & .019 & \\
\hline & Denial & -.13 & 2.24 & .026 & \\
\hline \multirow{3}{*}{ Male students } & Planning & .21 & 2.93 & .004 & \multirow{3}{*}{$.11^{* * *}$} \\
\hline & Drinking alcohol & -.20 & 2.79 & .006 & \\
\hline & Distraction & -.14 & 1.98 & .049 & \\
\hline \multirow{2}{*}{ Female students } & Active coping & .29 & 3.15 & .002 & \multirow{2}{*}{$.12^{* * *}$} \\
\hline & Distraction & -.23 & 2.53 & .013 & \\
\hline
\end{tabular}

Note. ${ }^{* *} p<.001$ 
that use avoidance and emotional expression in response to stress were found to be maladaptive".

High levels of stress were associated with poorer academic performance (Lumley \& Provenzano, 2003; Struthers, Perry, \& Menec, 2000). However, despite the preference of maladaptive coping strategies, female PE students had a higher average grade than male students. In a previous study, college men and women reported different coping strategies for different stressors (Brougham et al., 2009). It is possible that emotion-focused strategies are effective against stressors experienced by female students. Greater use of these strategies might be the result of socialization and acceptance of traditional sex roles (Dyson \& Renk, 2006). The masculinity and femininity of individuals also was related to the coping strategies. Regardless of biological sex, masculine individuals used more problem-focused coping strategies, whereas feminine individuals used more emotion-focused coping strategies (Dyson \& Renk, 2006; Renk \& Creasey, 2003). In addition, women are more neurotic and emotionally reactive than men, and strategies aimed at reducing emotional tension may be in their case effective. Neuroticism and emotional reactivity correlated positively with emotion-oriented coping style in a Polish population (Strelau et al., 2005).

Men preferred such task-oriented strategies as active coping and planning, while women preferred strategies that involved seeking support. Similar results were obtained in studies conducted across other cultures: Turkey (Kaya et al., 2007), Nepal (Sreeramareddy et al., 2007), Pakistan (Zafar \& Mubashir, 2012), the UK (Moffat et al., 2004) and the USA (Brougham et al., 2009). This suggests that coping is to some degree universal. Students' coping preferences are also determined by cultural factors. In our study, both men and women ranked turning to religion significantly lower in their hierarchy. Religion was the most frequently applied coping strategy by Nigerian students (Yussuf et al., 2013).

Regardless of gender, avoidance-oriented strategies (especially drinking alcohol, denial, and behavioural disengagement) were the strategies applied the least frequently. This contradicts results obtained in the studies by Romanowska-Tołłoczko (2011), in which students admitted to frequently drowning their stress in alcohol. This lack of consistency may to some degree be caused by the applied research tools, and the fact that research among students of the University of Physical Education in Warsaw was not anonymous. This could strengthen the distorting influence of the social approval variable.

In our study, avoidance-oriented strategies correlated negatively with academic achievement, while active coping was related to greater success in studies. The second hypothesis was thus confirmed. Previous studies also observed the following correlations between coping and academic achievement: positive in the case of task-oriented strategies, and negative in the case of emotion-oriented strategies (Struthers et al., 2000; Tamres, Janicki, \& Hedgeson, 2002). Based on the results of the cross sectional study it cannot be said that these strategies have a negative or positive impact on academic achievement. However, the predictive power of coping strategies for the average grade obtained in university courses was relatively weak in our study. It should be assumed that other factors are more significant. A Canadian study emphasized the importance of having a sense of control over one's academic achievements (Clifton, Perry, Roberts, \& Peter, 2008).

Previous studies indicate that students may use various coping strategies depending on the nature of a problem; they may use different strategies when facing difficulties in their relationships with their partners than those they use when facing difficulties in the course of their university education (Thornton et al., 2005). In the present study, the instructions for the COPE questionnaire did not indicate what difficult situations the aforementioned coping strategies concerned. This may be the reason why their correlation with academic achievement was not particularly strong.

Predictors of academic achievements were discovered to vary also according to gender, just as in the Canadian study (Clifton et al., 2008). The strategies most frequently used by male students were positive correlates and predictors of academic achievement, while in the case of women, strategies that correlated with average grades ranked slightly lower in their hierarchy. This does not prevent female students from obtaining higher grades.

This study has certain limitations. Only PE students from one university were examined, so the possibility to generalize the results is limited. In order to determine whether the observed differences are characteristic for students of other fields and specializations, further research is required.

The study encompassed only first-year students, i.e. the students who are most exposed to the many stressors associated with entering a higher level of education, changing one's place of residence, and, frequently, to a change in their family or financial situation. It would be interesting to conduct analogous research including students in the latter years of study, and even more interesting to investigate the students participating in this study again after a few years. It would then be possible to determine whether the observed correlations between coping strategies and academic achievement are characteristic only for first-year students, or are more universal in their application.

The study design was cross sectional, so we have obtained data about the relationships between coping strategies and academic achievement, not about the cause-effect dependencies. To determine them,
Gender as a factor in differentiating strategies 
longitudinal and prospective studies are needed. And finally, because the reliability of several scales was not satisfactory, these results should be considered approximate.

\section{RefERENCES}

Anshel, M. H., \& Delany, J. (2001). Sources of acute stress, cognitive appraisal, and coping strategies

Monika

Guszkowska,

Adriana

Zagórska-

Pachucka,

Anna Kuk,

Katarzyna

Skwarek of male and female child athletes. Journal of Sport Behavior, 24, 329-353.

Anshel, M. H., Jamieson, J., \& Raviv, S. (2001). Cognitive appraisals and coping strategies following acute stress among skilled competitive male and female athletes. Journal of Sport Behavior, 24, 75-94.

Brougham, R. R., Zail, C. M., Mendoza, C. M., \& Miller, J. R. (2009). Stress, sex differences, and coping strategies among college students. Current Psychology, 28, 85-97. doi: 10.1007/sl12144-009-9047-0

Carver, C. S., Scheier, M. F., \& Weintraub, J. K. (1989). Assessing coping strategies: A theoretically based approach. Journal of Personality and Social Psychology, 56, 267-283.

Chew-Graham, C. A., Rogers, A., \& Yassin, N. (2003). 'I wouldn't want it on my CV or their records': medical students' experiences of help-seeking for mental health problems. Medical Education, 37, 873-880.

Clifton, R. A., Perry, R. P., Roberts, L. W., \& Peter, T. (2008). Gender, psychosocial dispositions, and the academic achievement of college students. $R e^{-}$ search in Higher Education, 49, 684-703.

Dunkley, D. M., Blankstein, K. R., Halsall, J., Williams, M., \& Winkworth, G. (2000). The relation between perfectionism and distress: Hassles, coping, and perceived social support as mediators and moderators. Journal of Counseling Psychology, 47, 437-453.

Dwyer, A., \& Cummings, A. L. (2001). Stress, self-efficacy, social support, and coping strategies in university students. Canadian Journal of Counseling, 35, 208-220.

Dyson, R., \& Renk, K. (2006). Freshmen adaptation to university life: Depressive symptoms, stress, and coping. Journal of Clinical Psychology, 62, 12311244. doi: 10.1002/jclp.20295

Eaton, R. J., \& Bradley, G. (2008). The role of gender and negative affectivity in stressor appraisal and coping selection. International Journal of Stress Management, 15, 94-115.

Endler, N. S., \& Parker, J. D. (1990). Multidimensional assessment of coping: A critical evaluation. Journal of Personality and Social Psychology, 58, 844-854.

Fish, C., \& Nies, M. A. (1996). Health promotion needs of students in a college environment. Public Health Nurse, 13, 104-111.
Gan, Q., \& Anshel, M. H. (2006). Differences between elite and non-elite, male and female Chinese athletes on cognitive appraisal of stressful events in competitive sport. Journal of Sport Behavior, 29, 213-228.

Gomathi, K. G., Ahmed, S., \& Sreedharan, J. (2013). Causes of stress and coping strategies adopted by undergraduate health professions students in a University in the United Arab Emirates. Sultan Qaboos University Medical Journal, 13, 437-441.

Goyen, M. J., \& Anshel, M. H. (1998). Sources of acute competitive stress and use of coping strategies as a function of age and gender. Journal of Applied Developmental Psychology, 19, 469-486.

Guszkowska, M. (2003). Osobowość studentek pedagogiki (na przykładzie Wyższej Szkoły Pedagogicznej TWP) [Personality of pedagogy female students (on example of the Higher School of Pedagogy)]. Warszawa: Wyd. WSP TWP.

Guthrie, E. A., Black, D., Shaw, C. M., Hamilton, J., Creed, F. H., \& Tomenson, B. (1995). Embarking upon a medical career: psychological morbidity in first year medical students. Medical Education, 29, 337-341.

Hammermeister, J., \& Burton, D. (2004). Gender differences in coping with endurance sport stress: Are men form Mars and women from Venus? Journal of Sport Behavior, 27, 148-164.

Juczyński, Z., \& Ogińska-Bulik, N. (2009). Narzędzia pomiaru stresu $i$ radzenia sobie ze stresem [Psychometric tests measuring stress and coping with stress]. Warszawa: Pracownia Testów Psychologicznych PTP.

Kao, P. C., \& Craigie, P. (2013). Coping strategies of Taiwanese university students as predictors of English language learning anxiety. Social Behavior and Personality, 41, 411-420.

Kausar, R. (2010). Perceived stress, academic workloads and use of coping strategies University students. Journal of Behavioural Sciences, 20, 31-45.

Kaya, M., Genç, M., Kaya, B., \& Pehlivan, E. (2007). Prevalence of depressive symptoms, ways of coping, and related factors among medical school and health services higher education students. Türk Psikiyatri Dergisi, 18, 137-146.

Lane, A. W., Jones, L., \& Stevens, M. J. (2002). Coping with failure: The effects of self-esteem and coping on changes in self-efficacy. Journal of Sport Behavior, 25, 331-345.

Lazarus, R. S., \& Folkman, S. (1984). Psychological stress and the coping process. New York, NY: Springer.

Lumley, M. A., \& Provenzano, K. M. (2003). Stress management through written emotional disclosure improves academic performance among college students with physical symptoms. Journal of Educational Psychology, 95, 641-649. 
Moffat, K., McConnachie, A., Ross, S., \& Morrison, J. M. (2004). First year medical student stress and coping in a problem-based learning medical curriculum. Medical Education, 38, 482-491.

Niemi, P. M., \& Vainiomaki, P. T. (1999). Medical students' academic distress, coping and achievement strategies during the pre-clinical years. Teaching and Learning in Medicine, 11, 125-134.

Park, C. L., \& Adler, N. E. (2003). Coping styles as a predictor of health and well-being across the first year of medical school. Health Psychology, 22, 627-631.

Pierceall, E. A., \& Keim, M. C. (2007). Stress and coping strategies among community college students. Community College Journal of Research and Practice, 31, 702-712.

Pritchard, M. E., \& Wilson, G. (2006). Do coping styles change during the first semester of college? Journal of Social Psychology, 146, 125-127.

Pritchard, M. E., Wilson, G., \& Jamnitz, B. (2007). What predicts adjustment among college students? A longitudinal panel study. Journal of American College Health, 56, 15-21.

Renk, K., \& Creasey, G. L. (2003). The relationship of gender, gender identity, and coping strategies in late adolescents. Journal of Adolescence, 26, 159-168.

Robinson, M. D., \& Johnson, J. T. (1997). Is it emotion or is it stress? Gender stereotypes and the perception of subjective experience. Sex Roles, 36, 235-258.

Romanowska-Tołoczko, A. (2011). Styl życia studentów oceniany w kontekście zachowań zdrowotnych [University students' lifestyles in the context of their health behaviors]. Hygeia Public Health, 46, 89-93.

Rosołowska, J. (2003). Przyczyny stresu u studentów Wydziału Nauk o Zdrowiu Akademii Medycznej w Poznaniu [Causes of stress among Health Academy students in Poznan]. Pielegniarstwo Polskie, 15, 82-87.

Sasaki, M., \& Yamasaki, K. (2007). Stress coping and the adjustment process among university freshmen. Counseling Psychology Quarterly, 20, 51-67.

Shankar, P. R., Balasubramanium, R., Ramireddy, R., Diamante, P., Barton, B., \& Dwivedi, N. R. (2014). Stress and Coping Strategies among Premedical and Undergraduate Basic Science Medical Students in a Caribbean Medical School. Education in Medicine Journal, 6, e48-e56.

Silver, H. K., \& Glicken A. D. (1990). Medical student abuse. Incidence, severity, and significance. Journal of the American Medical Association, 263, 527-532.

Sreeramareddy, C. T., Shankar, P. R., Binu, V. S., Mukhopadhyay, C., Ray, B., \& Menezes, R. G. (2007). Psychological morbidity, sources of stress and coping strategies among undergraduate medical students of Nepal. BMC Medical Education, 7, 26.
Stanton, A. L., Kirk, S. B., Cameron, C. L., \& DanoffBurg, S. (2000). Coping through emotional approach: Scale construction and validation. Journal of Personality and Social Psychology, 78, 1150-1169.

Strelau, J., Jaworowska, A., Wrześniewski, K., \& Szczepaniak, P. (2005). Kwestionariusz Radzenia Sobie w Sytuacjach Stresowych CISS. Podręcznik [Questionnaire coping with stressful situations CISS. Textbook]. Warszawa: Pracownia Testów Psychologicznych PTP.

Struthers, C. W., Perry, R. P., \& Menec, V. H. (2000). An examination of the relationship among academic stress, coping, motivation, and performance in college. Research in Higher Education, 41, 581-592.

Tamres, L. K., Janicki D., \& Hedgeson V. S. (2002). Sex diffrerences in coping behavior: A meta-analytic review and an examination of relative coping. Personality and Social Psychology Review, 6, 2-30.

Thornton, B., Pickus, J., \& Aldrich, M. (2005). Ways of coping in relationship and achievement situations: Further consideration of gender and gender-role typing. Journal of Worry and Affective Experience, 1, 60-70.

Vitaliano, P. P., Russo, J., Carr, J. E., \& Heerwagen, J. H. (1984). Medical school pressures and their relationship to anxiety. Journal of Nervous and Mental Disease, 172, 730-736.

Wilczek-Rużyczka, E., \& Jabłeka, M. (2013). Job burnout syndrome and stress strategies of academic students. Zdrowie Publiczne, 123, 241-246.

Yussuf, A. D., Issa, B. A., Ajiboye P. O., \& Buhari O. I. (2013). The correlates of stress, coping styles and psychiatric morbidity in the first year of medical education at a Nigerian University. African Journal of Psychiatry, 16, 206-215.

Zafar, N., \& Mubashir, T. (2012). Emotional distress and coping strategies in university students after the death if parental figure. Journal of Behavioral Sciences, 22, 90-103.
Gender as a factor in differentiating strategies 